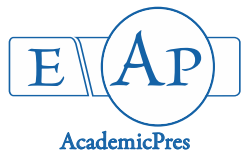

\title{
Essential Oil Composition and Antimicrobial Activity of Achillea biebersteinii Afan. (Asteraceae) from Erzincan Region, Turkey
}

\section{Emre SEVİNDİK ${ }^{1 *}$, Sinem AYDIN², Elif EREN APAYDIN³ Mustafa SÜRMEN ${ }^{4}$}

\author{
${ }^{1}$ Adnan Menderes University, Faculty of Agriculture, Department of Agricultural Biotechnology, South Campus, Cakmar, Aydin, \\ Turkey;ph.d-emre@hotmail.com (*correspondingauthor) \\ ${ }^{2}$ Giresun University, Faculty of Science and Arts, Department of Biology, Giresun, Turkey \\ ${ }^{3}$ Giresun University, Center Research Laboratory Application and Research Center, Giresun, Turkey \\ ${ }^{4}$ Adnan Menderes University, Faculty of Agriculture, Department of Field Crops, Aydin, Turkey
}

\begin{abstract}
In the present study, chemical composition determination and in vitro antimicrobial effects of essential oil of Achillea biebersteinii plant grown under Erzincan ecological conditions were evaluated. Extractions were carried out with Clevenger apparatus and essential oil composition was determined by Gas Chromatography-Mass Spectrometry (GC-MS). Microorganisms used for the antimicrobial studies were Salmonella enterica serovar. typhimirium ATCC 14028, Staphylococcus aureus subsp. aureus ATCC 25923, Yersinia pseudotuberculosis ATCC 911, Bacillus cereus 702 ROMA, Enterobacter aerogenes CCM 2531, Bacillus subtilis IMG 22 and Proteus vulgaris FMC 1. As a result, a total of 29 components were detected in Achillea biebersteinii. Among them, 1,8-cineole (20.36\%), cyclohexanone (8.39\%), 2-cyclohexen-1-one (5.38\%) and spathulenol (4.19\%) were found as the major components. For the in vitro antimicrobial activity determination of essential oil, disc diffusion method was used in our study. Furthermore, 12-14 mm zone diameters were detected in antimicrobial activity assay. The highest resistance zone was detected against $B$. subtilis with $14 \mathrm{~mm}$ diameter while the least resistance zone was detected against $Y$. pseudotuberculosis, E. aerogenes and $P$. vulgaris with $12 \mathrm{~mm}$ diameter. Consequently, it was concluded that the essential oil extracted from the $A$. biebersteinii grown under Erzincan ecological conditions had an inhibitory effects on the pathogenic microorganisms in used method.
\end{abstract}

Keywords: Achillea biebersteinii; antimicrobial activity; Erzincan; essential oil

family, expanding widely over the world and in Anatolia, show pharmacological activities. The plants in this family include sesquiterpene lactone metabolites having numerous biological activities such as antibacterial, antifungal, antihelminthic, anti-inflammatory, insecticide and

\section{Introduction}

Autoecological studies on economically important plants in Anatolia, which has a rich vegetation cover thanks to its geographical location and climate, are of great significance in order to understand the growth conditions and effective use of these plants (Çelik et al., 2004; Paksoy et al., 2006). The Asteraceae family, which is known to have the greatest number of species in the world, consists of approximately 23000 species and 1535 genera (Öztürk and Çetin, 2013; Nylinder and Anderberg, 2015). It has been reported that a large number of species of the Asteraceae antitumor, in addition to diterpenes and flavonoids (Picman, 1986; Shing et al., 2002; Ertürk, 2003; Bağcı et al., 2008). Achillea $\mathrm{L}$. is a large genus belonging to the family Asteraceae. The genus Achillea L. includes 59 taxa divided into 6 sections. Among them, 31 taxa are endemic to Turkey (53\%) (Arabaci, 2012; Aytac et al., 2016; Tabanca et al., 2016). The Achillea genus has a wide expansion range (Çelik and Akpulat, 2008). Differences in oil composition can be due to different environmental factors such as seasonality and developmental stage in addition to plant genetic type, especially in chemically polymorphic and

Received: 01 Jan 2018. Received in revised form: 29 Jun 2018. Accepted: 29 Aug 2018. Published online: 27 Sep 2018. 
perennial plants (Bezic et al., 2003). Terpenoids are the principle components of Achillea essential oils (Si et al., 2006; Nemeth and Bernath, 2008; Motavalizadehkakhky et al., 2013). Achillea biebersteinii is called "k1liçotu" (swordfish) and "sarı ot" (yellow weed) in Turkish and it is traditionally used to treat bleeding, infertility, asthma, stomach ache and cancer (Yildirım et al., 2015). The aim of the present study was to determine the essential oil contents of $A$. biebersteinii specimens grown under Erzincan ecological conditions, and to investigate their antimicrobial activity against various pathogenic bacteria.

\section{Materials and Methods}

\section{Plant material and GC-MS analysis}

Achillea biebersteinii samples of the plants were collected as study materials in July 2016 from Erzincan/Turkey surroundings (approximately 1,200 m altitude). Extractions were carried out with Clevenger apparatus (Basaran cam, Turkey and Misung Scientific Co., Korea) using water distillation (Balinova and Dyakov, 1974) and essential oil compositions were determined by Gas ChromatographyMass Spectrometry (GC-MS). Characterization of essential oil components was based on the library (Wiley and NIST) comparison with the mass spectra of the injected essential oil samples.

\section{Test bacteria and antimicrobial activity}

Seven bacterial strains were utilized to detect antimicrobial action of the essential oil. Salmonella enterica serovar typhimirium ATCC 14028 and Staphylococcus aureus subsp. aureus ATCC 25923 were obtained from Giresun Province Control Laboratory, Yersinia pseudotuberculosis ATCC 911 and Bacillus cereus 702 ROMA were obtained from Molecular Biology Department of Rize University. Enterobacter aerogenes CCM 2531, Bacillus subtilis IMG 22 and Proteus vulgaris FMC 1 were obtained from Department of Biology, Firat University. Bacterial strains were maintained on nutrient agar at $4{ }^{\circ} \mathrm{C}$. Examination of essential oil for antimicrobial efficiency was performed by the disc diffusion method. It was applied using a $24 \mathrm{~h}$ culture at $37^{\circ} \mathrm{C}$ in Mueller Hinton Broth. The turbidity of bacterial suspensions was adjusted to $108 \mathrm{cfu} / \mathrm{mL}$ (turbidity = McFarland standard 0.5). The oil was dissolved in DMSO (dimethyl sulfoxide) 1:2 (v/v) to give stock solution after which they were mixed for total solubilization at $180 \mathrm{rpm}$ for 10 minutes. Dissolved extracts was sterilized by using $0.45 \mu \mathrm{m}$ pore sized filter (Dobre et al., 2011). Inhibition zones of the essential oil were compared with standard antibiotics (tetracycline and gentamycine). Sterilized nutrient agar medium was poured in petri dishes and was allowed to solidify. The bacterial suspension inoculated into Mueller Hinton agar plates. Sterile discs were put $5 \mathrm{~mm}$ diameter) on the agar and $20 \mu \mathrm{L}$ A. biebersteinii essential oil, and $20 \mu \mathrm{L}$ DMSO were put on the discs, respectively. The inoculated plates were left in refrigerator for one hour then plates were incubated at $37^{\circ} \mathrm{C}$ overnight (Murray et al., 1995; Saric et al., 2009). Diameter of inhibition zones was measured in millimetres.

\section{Results and Discussion}

\section{Chemical composition of the essential oil}

Essential oils are complex mixtures obtained from the leaves, fruits, shells and roots of plants through distillation or pressing (Grassmann and Elstner, 2003; Wallace, 2004; Oussalah et al., 2006). Essential or volatile oils are natural products which are liquid at room temperature, easily crystallizable, usually colorless or pale yellow, volatile and strongly aromatic. Since they do not mix with water, they are different from oils although they are defined to be so (Grassmann and Elstner, 2003; Bicer et al., 2003; Kılıç, 2008; Evren and Tekgüler, 2011). In the hereby study, 29 components were isolated from $A$. biebersteinii, which formed $60.26 \%$ of the total essential oil amount. Based on the results of the gas chromatography-mass spectrometry analysis, the most commonly found substances were detected as; 1,8 -cineole $(20.36 \%)$, cyclohexanone (8.39\%), 2-cyclohexen-1-one (5.38\%) and spathulenol (4.19\%) (Table 1). There are many previous studies relating to the chemical composition of the essential oils obtained from $A$. biebersteinii. Bader et al. (2003) analyzed the essential oil composition of $A$. biebersteinii collected from Jordan. In their study, the concentrations of some essential oils from highest to lowest were as follows: cis-ascaridol (36.2\%), pcymene (31.6\%), carvenone oxide (6.4\%) and camphor (4.7\%). Barış et al. (2006) investigated the essential oil and biological activities of $A$. biebersteinii collected from Erzurum province, and reported piperitone (31.06\%), camphor (12.46\%), eucalyptol (10.98\%) and 1,8-cineole (10.93\%). Toncer et al. (2010) also investigated the essential oil composition of $A$. biebersteinii specimens collected from Bingöl / Genc, Mardin / Midyat, Siirt / Kurtalan and Elazığ / Kömürhan. In the essential oils obtained from the above locations in their study, the components with the highest amounts were as follows: Bingöl / Genc population, 1,8cineole (15.04\%), camphor (14.55\%) and d-piperitone (12.53\%); from Mardin /Midyat population, 1,8-cineole (31.76\%), camphor (27.46\%) and d-piperitone (11.97\%); from Siirt / Kurtalan population, ascardidol (61.95\%) and p-cymene (15.61\%); from Elazığ /Kömürhan population, 1,8-cineole (42.17\%), camphor (15.92\%) and $\alpha$-pinene (4.47\%). Rustaiyan et al. (1998) examined the essential oil composition of $A$. biebersteinii, which is also spread in Iran. Accordingly, the most commonly found substances were detected as ascidolide (37\%), piperitone (17\%) and camphor (12\%). Ghani et al. (2008) studied the composition of the essential oil of $A$. biebersteinii from Golmakan, a district of Razavi Khorasan province (North East of Iran) and they found 1, 8-cineole (32.82\%), carvacrol $(10.85 \%)$ and piperitone $(7.34 \%)$ components as the most abundant ones. Tabanca et al. (2011) investigated the essential oil composition of $A$. biebersteinii populations obtained from various provinces of Turkey. In the essential oil obtained from the Ankara-Kizllcahamam population, 1,8-cineole (36.0\%) and camphor (30.0\%); from the Ankara-Yenimahalle population, $p$-cymene (27.0\%) and camphor (24.5\%); from the Konya-Beyşehir population, 1,8-cineole (36.9\%) and camphor (15.6\%); from the Konya- 
330

Beyşehir-Akșehir population, 1,8-cineole (35.5\%) and camphor (35.5\%); from the Isparta-Yalvaç population, 1,8 cineole (34.3\%) and camphor (21.7\%) had the highest values. Typical for camphor are its antispasmodic, diuretic, antirheumatic and sedative effects. The biological function of the chemical components is not limited by their antimicrobial activity; some of them have antioxidant (limonene, pinene), antitumor (linalool, borneol), antiinflammatory (sabinene, pinene) and analgesic functions (citral) as well (Teneva et al., 2016). Considering the current study reporting essential oils from the $A$. biebersteinii specimens, the major components were detected as; 1, 8-cineole (20.36\%), cyclohexanone (8.39\%) and spathulenol (4.19\%). In conclusion, the findings obtained from various studies were found to be different from the findings of the present study. This may be explained by the fact that the essential oil composition may have different qualities and quantities under different geographical and environmental conditions as well as at different periods of plant growth (Mazandarani et al., 2013).

\section{Antimicrobial activity}

The most commonly studied dimension of essential oils is related to antimicrobial activities. These oils have antimicrobial effects against a variety of microorganisms including gram (-) and gram $(+)$ bacteria. As the essential oils are complex mixtures comprising different components, action levels thereof vary depending on diversity and amount of the active substances. Despite having limited information relating to their mechanisms of action, it seems to be associated with lipophilic features and chemical structures of the oils (Bayaz, 2014). For the in vitro antimicrobial activity determination of essential oil, disc diffusion method was used in our study. The results were compared to the standard antimicrobial agents such as gentamycine and tetracycline. Zone diameters of $12 \mathrm{~mm}-14$ $\mathrm{mm}$ were detected in disc diffusion methods. Achillea biebersteinii essential oil was effective against Salmonella enterica serovar typhimurium Staphylococcus aureus subsp. aureus, Yersinia pseudotuberculosis, Bacillus cereus, Enterobacter aerogenes, Bacillus subtilis and Proteus vulgaris. The widest resistance zone was against Bacillus subtilis with $14 \mathrm{~mm}$ diameter while the smallest resistance zone was detected against $Y$. pseudotuberculosis, $E$. aerogenes and $P$. vulgaris with $12 \mathrm{~mm}$ diameter (Table 2). The essential oil exhibited lower activity than that of gentamycine, but it exhibited similar activity to that of tetracycline. Barış et al. (2006) examined antimicrobial activity of essential oil and methanol extract from $A$. biebersteinii. The methanol extract was not active against any studied microorganisms. On the other hand, essential oil inhibited the growth of 6 bacterial species tested. The essential oils also inhibit antifungal action as reported by Sökmen et al. (2004) who assessed antimicrobial activity of essential oil from $A$. biebersteinii. In their study, the essential oil displayed strong activity against Candida albicans, Clostridium perfringens, Streptococcus pneumoniae, Staphylococcus aureus, Bacillus cereus, Escherichia coli and Mycobacterium smegmatis (Sökmen et al., 2004). Likewise, we observed activity against $S$. aureus and B. cereus in our study. Kotan et al. (2010) examined chemical composition of the essential oil of $A$. biebersteinii by GC-MS and tested antimicrobial effect of essential oil against 25 plant pathogenic bacteria. We also studied antimicrobial efficiency of $A$. biebersteinii, but it was obtained different results when compared to previous studies. These different results may have been obtained due

Table 1. Essential oil composition of Achillea biebersteinii

\begin{tabular}{|c|c|c|c|c|c|}
\hline $\begin{array}{l}\text { RT } \\
(\mathrm{min})\end{array}$ & Component & Quantity (\%) & $\mathrm{RT}(\min )$ & Component & Quantity (\%) \\
\hline 6.524 & $\beta$-pinene & 0.98 & 17.301 & 2-heptyl furan & 0.18 \\
\hline 6.806 & 3-octanol & 0.23 & 17.486 & 5-amino-6-chloro-4-(2-ethenylamino)pyrimidine & 1.48 \\
\hline 7.606 & 1,8-cineole & 20.36 & 19.501 & $\begin{array}{c}\text { bicyclo[4.1.0]heptan-3-ol, 4-hydroperoxy-4,7,7- } \\
\text { trimethyl }\end{array}$ & 1.59 \\
\hline 7.917 & $\begin{array}{l}\text { 4-hydroxy-6-methyl2H-pyran-2- } \\
\text { one }\end{array}$ & 0.56 & 20.093 & mint furanone 2 & 0.33 \\
\hline 9.902 & trans-pinocarveol & 0.75 & 21.568 & caryophyllene oxide & 2.83 \\
\hline 10.035 & camphor & 0.66 & 21.367 & (+) spathulenol & 4.19 \\
\hline 10.509 & cyclohexanone & 8.39 & 21.989 & $\alpha$-pinene & 2.25 \\
\hline 10.561 & borneol & 3.59 & 22.841 & caryophylla- $4(12), 8(13)$ diene $5 \beta$-ol & 0.18 \\
\hline 11.028 & menthol & 0.25 & 23.278 & t-Muurolol & 0.36 \\
\hline 11.087 & 3-cyclohexene-1-methanol & 0.72 & 23.686 & caryophyllenol-II & 0.62 \\
\hline 11.590 & bicyclo[3.1.1]hept-3-en-2-one & 0.16 & 23.900 & 1-cyclohexene-1-butanol & 0.63 \\
\hline 12.057 & bicyclo[2.2.1] heptan-2-ol & 1.34 & 28.078 & benzothiazole & 0.25 \\
\hline 15.220 & 2-cyclohexen-1-one & 5.38 & 30.011 & hexadecanoic acid & 0.76 \\
\hline 16.568 & $\begin{array}{l}\text { 1-methoxy-4- } \\
\text { (1-methylethenyl)benzene }\end{array}$ & 0.56 & 37.121 & furane-3-carbohydrazide & 0.27 \\
\hline 16.886 & $\begin{array}{c}\text { 1,3-dimethoxy-2,5- } \\
\text { dimethylbenzene }\end{array}$ & 0.41 & & Total: & 60.26 \\
\hline
\end{tabular}

RT: Retention time 
Table 2. Antimicrobial activity (inhibition zones) of the essential oils from Achillea biebersteinii

\begin{tabular}{cccc}
\hline Microorganism & A. biebersteinii & Tetracycline & Gentamycine \\
\cline { 2 - 3 } S. enterica serovar typhimirium (-) & IZ, mm & IZ, mm & $15 \pm 0.00$ \\
Y. pseudotuberculosis ATCC 911 (-) & $13.5 \pm 0.70$ & NA & $17.5 \pm 0.70$ \\
E. aerogenes CCM 2531 (-) & $12 \pm 0.00$ & $11.5 \pm 0.70$ & $11 \pm 1.41$ \\
B. subtilis IMG 22 (+) & $12 \pm 2.82$ & $18.5 \pm 2.12$ & $16.5 \pm 0.70$ \\
S. aureus subsp. aureus ATCC 25923(+) & $14 \pm 0.00$ & $11 \pm 1.41$ & $19.5 \pm 0.70$ \\
P. vulgaris FMC 1 (-) & $13.5 \pm 0.70$ & $10 \pm 0.00$ & $15 \pm 0.00$ \\
B. cereus 702 ROMA (+) & $12 \pm 2.82$ & $13 \pm 0.00$ & $17 \pm 0.00$ \\
\hline IZ-Inhibition zones & &
\end{tabular}

to using different bacterial species, collecting plant specimens from different locations and using different amounts of essential oil against test microorganisms. Kordali et al. (2009) carried out a study about antifungal activity of Achillea gypsicola and Achillea biebersteinii.

There are many studies related to antimicrobial activity of different Achillea species. For example, Bezic et al. (2003) investigated volatile constituents and antimicrobial potentials of Achillea clavennae, and they found important decline of bacterial growth against Escherichia coli and Proteus mirabilis. On the other hand, Bacillus cereus, Bacillus subtilis and Streptococcus faecalis were resistant to the essential oil with inhibition zones between $4 \mathrm{~mm}$ and 6.5 $\mathrm{mm}$. In a study which was carried out by Candan et al. (2003), essential oil of Achillea millefolium subsp. millefolium manifested antimicrobial activity against Streptococcus pneumoniae, Clostridium perfringens, Candida albicans, Mycobacterium smegmatis, Acinetobacter lwoffi and Candida krusei. Başer et al. (2002) worked out composition and antimicrobial activity of the essential oil of Achillea multifida. Plant pathogenic bacteria inhibition potential of Achillea millefolium was investigated by Vasinauskiene et al. (2006). The strength of the antimicrobial property has been reported to vary according to the used extract type, collecting plant materials from different locations, used extract concentration, and microorganisms tried (Srivastava et al., 2013).

\section{Conclusions}

Considering the current study with the essential oils from the of $A$. biebersteinii plants, the major compnents were detected as, 1,8-cineole (20.36\%), cyclohexanone (8.39\%), 2-cyclohexen-1-one (5.38\%) and spathulenol (4.19\%). According to the results obtained in the hereby study, it is possible to conclude that antimicrobial activity of the essential oil is slightly lower in comparison to antibiotics (tetracycline and gentamycine) effect on tested seven different bacteria genus (S. enterica serovar typhimirium, $Y$. pseudotuberculosis, E. aerogenes, $B$. subtilis, $S$. aureus subsp. aureus, $P$. vulgaris and $B$. cereus). These findings may be a valuable resource for further biotechnological, biodiversity, pharmaceutical and medical studies. It will also help to understand the importance of the biological diversity and conservation biology efforts.

\section{References}

Arabaci A (2012). Achillea L. In: Guner A, AslanS, Ekim T, Vural M, Babac MT(Eds). Turkiye Bitkileri Listesi (Damarli Bitkiler) Nezahat Gokyigit Botanik Bahcesive Flora Arastirmalari Dernegi Yayini, Istanbul.

Aytac Z, Duman H, Ekici M (2016). Two new Achillea L. (Asteraceae) species from Turkey. Turkish Journal of Botany 40:373-379.

Bader A, Flamini G, Cioni PL, Morelli I (2003). Essential oil composition of Achillea santolina L. and Achillea biebersteinii Afan. collected in Jordan. Flavour and Fragrance Journal 18(1):36-38.

Bağc E, Koçak A, Yüce E (2008). The composition of the essential oils of two Achillea L. (Achillea wilhelmsii C. Koch. ve Achillea schischkinii Sosn.) species. Science and Engineering Journal of Firat University 20(2):251-255.

Balinova A, Dyakov G (1974). Improved apparatus for microdistillation of rose flower. Agricultural Science 11:79-85.

Bariş Ö, Güllüce M, Şahin F, Özer H, Kiliç H, Özkan H, Özbek T (2006). Biological activities of the essential oil and methanol extract of Achillea biebersteinii Afan. (Asteraceae). Turkish Journal of Biology30(2):65-73.

Başer KHC, Demirci B, Demirci F, Güleryüz G (2002). Composition and antimicrobial activity of the essential oil of Achillea multifida. Planta Medica68:941-943.

Bayaz M (2014). Essential oils: antimicrobial, antioxidant and antimutagenic activities. Academic Food Journal 12(3):45-53.

Bezic N, Skocibucic M, Dunkic V, Radonic A (2003). Composition and antimicrobial activity of Achillea clavennae L. essential oil. Phytotherapy Research 17:1037-1040.

Bicer A, Özkan G, Ergen A (2003). Lavanta bitkisi çiçeklerinden süperkritik $\mathrm{CO}_{2}$ ile uçucu yağların ekstraksiyonuna basıncın etkisi. G.Ü. Fen Bilimleri Dergisi 16(4):717-723.

Candan F, Ünlü M, Tepe B, Daferera D, Polissiou M, Sökmen A, Akpulat HA (2003). Antioxidant and antimicrobial activity of the essential oil and methanol extracts of Achillea millefolium subsp. millefolium Afan. (Asteraceae).Journal of Ethnopharmacology 87(2-3):215-220.

Celik N, Akpulat HA (2008). Achillea sivasica (Asteraceae: sect. Babounya (DC.) O. Hoffm.), a new species from inner Anatolia, Turkey. Kew Bulletin 63:485-489.

Çelik A, Çiçek M, Semiz G, Karıncalı M (2004). Taxonomical and ecological investigations on some geophytes growing around Denizli Province(Turkey). Turkish Journal of Botany 28:205-211. 
332

Dobre AA, Gagiu V, Niculita P (2011). Preliminary studies on the antimicrobial activity of essential oils against food borne bacteria and toxigenic fungi. The Annals of the University Dunarea de Jos of Galati. Fascicle VI-Food Technology35(2):16-26.

Ertürk Ö (2003). Scorzonera mollis Bieb. (Compositae) Bitkisinin Antimikrobiyal Aktivitesi, Çevre Koruma Dergisi 47:27-31.

Evren M, Tekgüler B (2011). Uçucu yağların antimikrobiyel özellikleri. Elektronik Mikrobiyoloji Dergisi 9(3):28-40.

Ghani A, Azizi M, Hassanzadeh-Khayyat M, Pahlavanpour AA (2008). Essential oil composition of Achillea eriophora, A. nobilis, A. biebersteinit and $A$. wilhelmsii from Iran.Journal of Essential Oil Bearing Plants 11(5):460-467.

Grassmann J, Elstner EF (2003). Essential oils/properties and uses. Encyclopaedia of Food Science, Food Technology and Nutrition (Elsevier Science Ltd) pp2177-2184.

Kulıç A (2008). Uçucu yağ elde etme yöntemleri. Bartın Orman Fakültesi Dergisi. 10(13):37-45.

Kordali Ş, Çakır A, Akcin TA, Mete E, Akcin A, Aydın T, Kulıç H (2009). Antifungal and herbicidal properties of essential oils and n-hexane extracts of Achillea gypsicola Hub-Mor and Achillea bieberstenii Afan. (Asteraceae). Industrial Crops and Products 29(2-3):562-570.

Kotan R, Çakır A, Dadaşoğlu F, Aydın T, Çakmakç R, Özer H, Kordali S, Mete E, Dikbaş N (2010). Antibacterial activities of essential oils and extracts of Turkish Achillea, Satureja and Thymus species against plant pathogenic bacteria. Journal of the Science of Food and Agriculture 90(1):145-160.

Mazandarani M, Mirdeilami SZ, Pessarakli M (2013). Essential oil composition and antibacterial activity of Achillea millefolium $\mathrm{L}$. from different regions in north east of Iran. Journal of Medicinal Plants Research 7(16):1063-1069.

Motavalizadehkakhky A, Shafaghat A, Zamani HA, Akhlaghi H, Mohammadhosseini, M, Mehrzad J, Ebrahimi Z (2013). Compositions and the in vitro antimicrobial activities of the essential oils and extracts of two Achillea species from Iran.Journal of Medicinal Plants Research 7(19):1280-1292.

Murray PR, Baron EJ, Pfaller MA, Tenovar FC, Yolke RH(1995). Manual ofClinical Microbiology. ASM Press, Washington D.C.

Nemeth E, Bernath J (2008). Biological activities of yarrow species (Achillea spp.). Current Pharmaceutical Design 14(29):3151-3167.

Nylinder S, Anderberg AA (2015). Phylogeny of the Inuleae (Asteraceae) with special emphasis on the Inuleae-Plucheinae. Taxon 64(1):110-130.

Oussalah M, Caillet S, Saucier L, Lacroix M. (2006). Antimicrobial effects of selected plant essential oils on the growth of a Pseudomonas putida strain isolated from meat. Meat Science 73:236-244.

Öztürk M, Çetin Ö (2013). Inula tuzgoluensis (Asteraceae), a new species from Central Anatolia, Turkey. Turkish Journal of Botany 37:825-835.

Paksoy MY, Selvi S, Sevindik E, Uysal H (2016). Soil content in the Anacyclus L.(Asteraceae) genus growing in Turkey. Turkish Journal of LifeSciences 1(1):8-12.
Picman AK (1986). Biological activities of sesquiterpene lactones. Biochemical Systematics and Ecology 14(3):225-281.

Rustaiyan A, Komeilizadeh H, Shariatpanahi MS, Jassbi AR, Masoudi S (1998). Comparative study of the essential oils of three Achillea species from Iran. Journal of Essential Oil Research 10(2):207-209.

Saric CL, Cabarkapa SI, Beljkas MB, Misan CA, Sakac BM, Plavsic VD (2009). Antimicrobial activity of plant extracts from Serbia. Food Processing Quality and Safety 1(2):1-5.

Shing B, Sahu PM, Sharma MK (2002). Anti-inflammatory and antimicrobial activities of Triterpenoids from Strobilanthes callosus, Ness. Phytomedicine 9:355-359.

SiXT,Zhang ML, ShiQW, Kiyota H (2006). Chemical constituents of the plants in the genus Achillea. Chemistry and Biodiversity 3:1163-1179.

Sökmen A, Sökmen M, Daferera D, Polissiou M, Candan F, Ünlü M. Akpulat HA (2004). The in vitro antioxidant and antimicrobial activities of the essential oil and methanol extracts of Achillea biebersteinii Afan. (Asteraceae). Phytotheraphy Research 18:451-456.

Srivastava P, Logesh AR, Upreti DK, Dhole TN, Srivastava A (2013). In vitro evaluation of some Indian lichens against human pathogenic bacteria. Mycosphere 4(4):734743.

Tabanca N, Demirci B, Aytaç Z, Baser KHC (2016). Chemical composition of Achillea schischkinii Sosn., an endemic species from Turkey. Natural Volatiles andEssential Oils 3:2428.

Tabanca N, Demirci B, Gurbuez I, Demirci F, Becnel JJ, Wedge DE, Baser $\mathrm{KH}$ (2011).Essential oil composition of five collections of Achillea biebersteinii from central Turkey and their antifungal and insecticidal activity. Natural Product Communications 6(5):701-706.

Teneva D, Denkova Z, Goranov B, Denkova R, Kostov G, Atanasova T, Merdzhanov P (2016). Chemical composition and antimicrobial activity of essential oils from black pepper, cumin, coriander and cardamom against some pathogenic microorganisms. Acta Universitatis Cibiniensis Series E. Food Technology 20(2):39-52.

Toncer O, Basbag S, Karaman S, Diraz E, Basbag M (2010). Chemical composition of the essential oils of some Achillea species growing wild in Turkey. International Journal of Agriculture and Biology 12(4):527530.

Vasinauskiene M, Radusiene J, Zitikaite I, Surviliene E (2006). Antibacterial activities of essential oils from aromatic and medicinal plants against growth of phytopathogenic bacteria. Agronomy Research 4:437-440.

Wallace RJ (2004). Antimicrobial properties of plant secondary metabolites. Proceeding of the Nutrition Society 63:621-629.

Yildirim B, Ekici K, Rezaeieh KAP (2015). Volatile oil components and antibacterial activity of Acbillea biebersteinii Afan. from lake Van Basin, Turkey. Asian Journal ofChemistry 27(12):4686-4688. 